\title{
A review of bordered brown lacewing Megalomus hirtus (Neuroptera: Hemerobiidae) distribution in Scotland
}

\author{
S. Burgess ${ }^{1} \&$ N.A. Littlewood ${ }^{2}$ \\ ${ }^{1}$ Buglife, Balallan House, 24 Allan Park, Stirling FK8 2QG \\ ${ }^{2}$ SRUC, Craibstone, Aberdeen AB21 9YA \\ ${ }^{1}$ E-mail: suzanne.burgess@ buglife.org.uk
}

\begin{abstract}
In the U.K., the bordered brown lacewing (Megalomus hirtus) is associated with aphids and other insects on wood sage (Teucrium scorodonia) growing on rocky exposed slopes. The species is widely distributed across northern and central Europe. However, before 2019 it was recorded from only three sites in the U.K., all in Scotland, at Holyrood Park in Edinburgh, and at Muchalls and St. Cyrus, both in Aberdeenshire. Surveys in 2019 discovered the lacewing in a new area of Holyrood Park and at several new sites from Stonehaven to Portlethen village in Aberdeenshire. Only adults were recorded, and all were collected from wood sage. The surveys have also identified other areas and sites that should be visited to determine the distribution of the bordered brown lacewing in Scotland.
\end{abstract}

\section{INTRODUCTION}

The bordered brown lacewing Megalomus hirtus (L., 1761) (Fig 1.) is approximately $1 \mathrm{~cm}$ in length and can be identified by the wide costal space on both forewings (Plant, 1997). Another key character used to identify this species is the five (sometimes six or seven) radial veins that branch from the humeral vein on both forewings. The patterning and hair on its wings and body are not diagnostic features, as this species looks similar to other species of brown lacewing in the Hemerobiidae family.

Adults of bordered brown lacewing have been recorded from June to August, although they may be active earlier and later depending on the local climate (Plant, 1994; Littlewood \& Stockan, 2013). Adults appear to spend most of the day deep amongst vegetation and are unwilling to move, even when disturbed (Plant, 1997; Nielsen, 2015).

Adult females lay each egg individually and on the underside of the leaves of wood sage and potentially other plant species (Nielsen, 2015). The larval stage has been known to last up to four years and, when ready to pupate, they will overwinter in their cocoons to emerge as adults the following year. In the U.K. this species is associated with aphids and other insects on wood sage growing on rocky hill-sides and under cliffs (Plant, 1994). In Europe it may not be confined to this plant having been recorded from hazels (Corylus spp.) and other plant species (Plant, 1997; Nielsen, 2015).

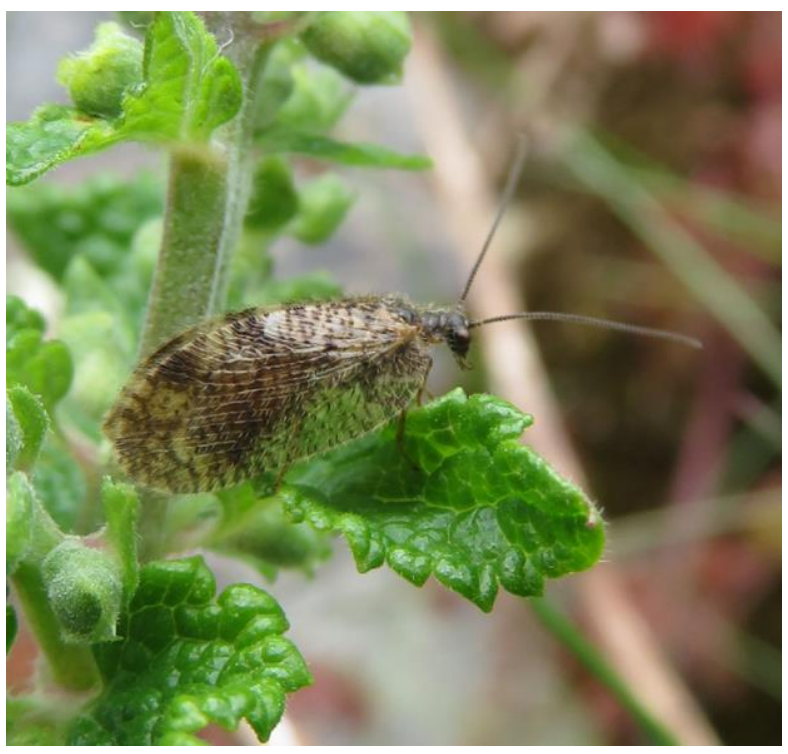

Fig. 1. Bordered brown lacewing (Megalomus hirtus) adult (length $1 \mathrm{~cm}$ ) on wood sage (Teucrium scorodonia), Skatie Shore, Aberdeenshire, Scotland, 1st July 2019. (Photo: S. Burgess)

Although widely distributed across mainland Europe, in the U.K. this species has a very restricted distribution, being found only in Scotland. Before 2019, there were only three known sites for the species in Scotland, at Holyrood Park in Edinburgh, and in Aberdeenshire at Doonie Point by Bridge of Muchalls and St. Cyrus (Burgess \& Lindsay, 2019). Although there are some reports from other sites, none is adequately documented. Indeed a hectad near Aberdeen, NJ80, that appeared in the distribution atlas covering this group (Plant, 1994) has now been removed from the Lacewing and Allies Record Scheme database, as it was likely included due to confusion with Muchalls (Littlewood, 2018).

As a result of its restricted distribution in Scotland the species is on the Scottish Biodiversity List (SBL) as a priority species. Given the poor knowledge of its current distribution there is a pressing need to determine its status in the U.K. This paper provides information on the results of surveys conducted in Holyrood Park, Edinburgh, in Aberdeenshire, and in other sites, which gives an indication of the current status of the species in Scotland. 


\section{SURVEYS}

\section{Holyrood Park}

Adults of the bordered brown lacewing have periodically been recorded from their stronghold at Holyrood Park, with most recent records in 1980, 1995, 2015 and during the current Buglife led surveys in 2018 and 2019 (Littlewood \& Stockan, 2013; Smith \& Burgess, 2015; Burgess \& Lindsay, 2019; Lemon \& Burgess, 2019). During the survey in 2015, one adult was recorded on 30th June on a rocky slope near the summit of Arthur's Seat (NT27527288) (Smith \& Burgess, 2015). With only one adult being recorded in 1995 and then this singleton over a three-month sampling period in 2015, Buglife, with funding from Scottish Natural Heritage ( $\mathrm{SNH}$ ), organised surveys with members of the public in 2018 and again in 2019. Permission for the surveys was granted by Historic Environment Scotland (HES) who manage the park and $\mathrm{SNH}$, as Holyrood Park is a designated Site of Special Scientific Interest (SSSI).

During the survey in 2018, a total of 14 adults was recorded in early June along the rocky outcrops of Salisbury Crags from NT26887348 to NT26747317 (Lemon \& Burgess, 2019). The main path along Salisbury Crags has since been closed to members of the public for health and safety reasons and surveys in 2019 focused on other areas of Holyrood Park. In 2019, a further 12 adults were recorded in late June and early July at rocky outcrops below St. Anthony's Chapel at NT27407370 and NT27577370 (Burgess \& Lindsay, 2019). Whinny Hill (NT27717318) within Holyrood Park was also visited in July 2019 and although the area has plentiful wood sage, no lacewings were recorded (Burgess \& Lindsay, 2019). During both visits in 2019 a ranger from HES was present and learned how to survey for this species. The rangers aim to continue monitoring for the species and determine if the lacewing is found across a much larger area of Holyrood Park.

\section{Aberdeenshire}

Muchalls in Aberdeenshire has historic records of the species up to 1916, when a short series of adults was taken (King, 1917). There were no further records until one adult was taken by Doonie Point, Muchalls (NO90159095) on 7th July 2018 (Littlewood, 2018).

The area at Doonie Point was visited by the authors on 8th May 2019 to look at the condition of the habitat and identify new areas for a public survey to be held when adults are known to be active later in the summer (Burgess \& Lindsay, 2019). It was decided to hold this public survey at a coastal site slightly further south of Doonie Point (and with easier access for the public) at Skatie Shore and Perthumie Bay. This area is just north of the town of Stonehaven and is part of Garron Point SSSI, a rocky promontory with adjoining coastal strips that have steep grassy cliffs, vegetated shingle and areas of species-rich grassland. The site has been designated as an SSSI to protect a combination of geological and biological features including the SBL priority species narrow-mouthed whorl snail (Vertigo angustior) and northern brown argus butterfly (Aricia artaxerxes). The public survey held here on 1st July recorded ten adults of the bordered brown lacewing from several patches of wood sage from NO89038780 to NO89048813 (Fig. 2) (Burgess \& Lindsay, 2019).

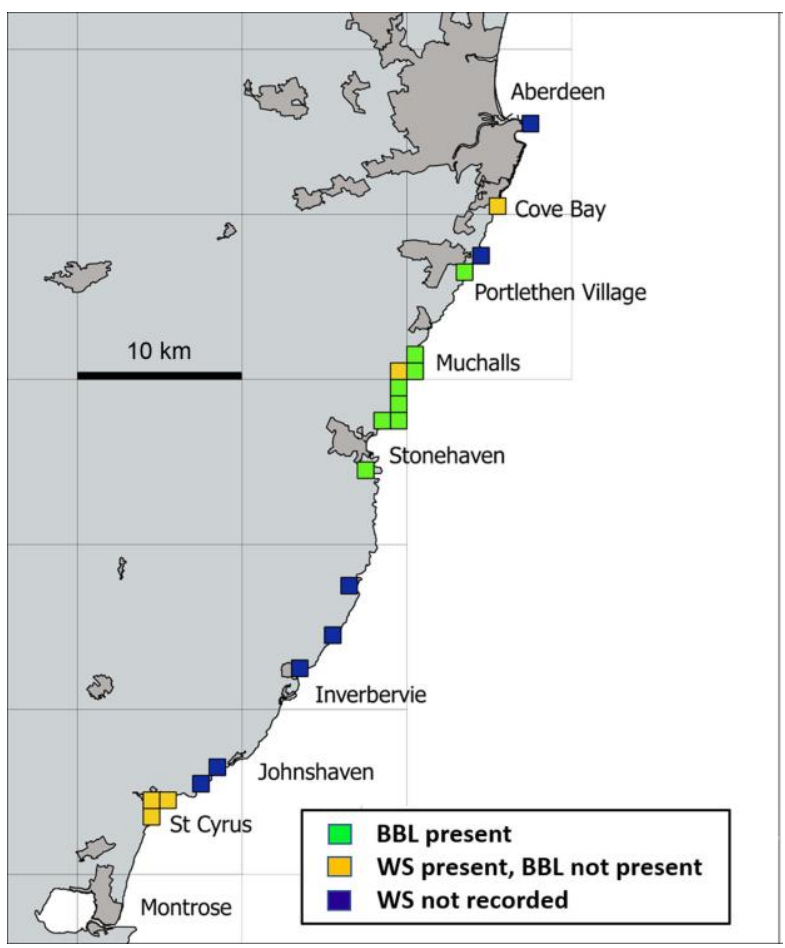

Fig. 2. Map of part of east Aberdeenshire, Scotland showing results of surveys in 2019. BBL, bordered brown lacewing (Megalomus hirtus); WS, wood sage (Teucrium scorodonia).

After the public survey on 1st July, N.A.L. travelled north of the bay to search other areas of wood sage found on rocky outcrops along the coast and successfully found an adult at NO89288908 (Fig. 2). The war memorial just south of Stonehaven was visited later on the same day and an adult was recorded on wood sage at NO87808481 (Fig. 2). Later that week, N.A.L. recorded adults of the bordered brown lacewing along other areas of the coast and identified other sites that supported wood sage where the lacewing was not recorded but should be revisited (Fig. 2). At Doonie Point (NO90139094) two adults were recorded in the same area as they were recorded in 2018 (Fig. 2). Another adult was recorded at Portlethen Village (NO93349605) (Fig. 2) which only had small patches of wood sage that were difficult to access being on steep slopes. Another was recorded just outside of Muchalls village (NO90259165) (Fig. 2). A further four adults, all from the same clump of wood sage, were recorded at Craigeven Bay (NO88748752) (Fig. 2), a short way south of Garron Point.

\section{Other sites}

There are historical records of bordered brown lacewing from another coastal site at the southern extremity of Aberdeenshire, at St. Cyrus National Nature Reserve, where the species was last recorded in 1935 (Plant, 1997). This site was visited during surveys in 2015 , 2018 and 2019, although each has been unsuccessful in recording the bordered brown lacewing (Smith \& 
Burgess, 2015; Lemon \& Burgess, 2019; Burgess \& Lindsay, 2019). Wood sage is plentiful across this National Nature Reserve and the habitat is similar to where the lacewing has been recorded along the Aberdeenshire coast with several patches of wood sage on exposed rocky outcrops.

Blackford Hill Local Nature Reserve within the Hermitage of Braids in Edinburgh was also visited during surveys in 2015, 2018 and 2019 (Smith \& Burgess, 2015; Lemon \& Burgess, 2019; Burgess \& Lindsay, 2019). Blackford Hill is $3 \mathrm{~km}$ south-west of Holyrood Park and supports similar habitat, although within a much smaller area. There are several patches of wood sage, some of which are on exposed rocky cliffs. Surveys at this site were unsuccessful in recording the bordered brown lacewing although the quality of habitat that could support the species was assessed and found to be poor due to shading by gorse (Ulex europaeus). This invasive plant is currently being controlled and removed by the rangers who manage the site, which will significantly improve the quality of habitat for the lacewing (should it be present here) and other wildlife.

\section{CONCLUSION}

As a result of these surveys, the bordered brown lacewing has been discovered at several new sites along the Aberdeenshire coast and in Holyrood Park; and additional potentially suitable areas have been identified for future surveys. It is important to continue the monitoring of this species to determine its health and distribution in Scotland, and to ensure its long-term survival.

\section{ACKNOWLEDGEMENTS}

Buglife would like to thank SNH for providing funding to allow surveys for the bordered brown lacewing that have helped rediscover this rare species in Scotland. We would also like to thank all the volunteers who have participated in the surveys.

\section{REFERENCES}

Burgess, S. \& Lindsay, J. (2019). Bordered Brown Lacewing Project Report. Buglife. https://cdn.buglife.org.uk/2019/12/Bordered-brown -lacewing-report-2019-final.pdf Accessed 29th April 2020.

King, J.J.F.X. (1917). Occurrence of Megalomus hirtus L. in Kincardineshire. Entomologist's Monthly Magazine 53, 87.

Lemon, A. \& Burgess, S. (2019). Bordered Brown Lacewing Project Report. Buglife. https://cdn.buglife.org.uk/2019/07/Bordered-brown -lacewing-report-2018-final.pdf Accessed 29th April 2020.

Littlewood, N.A. (2018). Megalomus hirtus (L., 1761) (Neur.: Hemerobiidae) rediscovered in Aberdeenshire and investigation of an old record. Entomologist's Record and Journal of Variation 130, 274- 276.

Littlewood, N.A. \& Stockan, J.A. (2013). Surveillance of priority terrestrial invertebrates in Scotland. Scottish Natural Heritage Commissioned Report No.
609. p 115-116. https://www.nls.uk/emonographs/2013/609.pdf Accessed 29th April 2020.

Nielsen, O.F. (2015). Danmarks Netvinger. Apollo Books, Denmark.

Plant, C.W. (1994). Provisional Atlas of Lacewings and Allied Insects (Neuroptera, Megaloptera, Raphidioptera and Mecoptera) of Britain and Ireland. Biological Records Centre, Huntingdon.

Plant, C.W. (1997). A key to the adults of British lacewings and their allies. Field Studies 9, 179-269.

Smith, M. \& Burgess, S. (2015). Rediscovering the Bordered brown lacewing (Megalomus hirtus). A survey in Holyrood Park SSSI. Buglife. https://cdn.buglife.org.uk/2019/07/Final-Borderedbrown-lacewing-report-MikeSmith_0.pdf Accessed 29th April 2020. 